Information for Authors
Avis aux auteurs
The purpose of the Canadian Journal of Philosophy is the publication in Canada of philosophical work of high quality, in English or French, and in any field of philosophy. All submissions are given blind editorial review; those of departmental colleagues are externally refereed.

Manuscripts should be sent in triplicate to: Executive Secretary, Canadian Journal of Philosophy, Department of Philosophy, University of Lethbridge, Lethbridge, Alberta, Canada T1K 3M4. It is preferred that manuscripts be typed double-spaced, including quotes and footnotes. In general, the Canadian Journal of Philosophy follows The University of Chicago Manual of Style. Footnotes should be numbered consecutively and assembled on separate pages at the end of the manuscript. Manuscripts should be prepared for blind review, which means they should contain no self-identifying references in either text or footnotes. Manuscripts will not be returned unless return postage is prepaid by cheque, money-order, reply coupons, or Canadian stamps.

Authors will receive, without charge, 25 copies of their articles. Additional offprints may be ordered when the proofs are returned to the publisher.

The articles in CJP are indexed in The Philosophers' Index, Bowling Green, Ohio, USA, in the Répertoire bibliographique de la philosophie, Louvain, Belgium, and in the Canadian Periodical Index.

All enquiries of an editorial nature should be directed to the Executive Secretary at the above address.

The Canadian Journal of Philosophy a pour objet la publication canadienne, en langues anglaise ou française, d'études philosophiques de haut niveau, quel que soit le domaine philosophique auxquelles elles appartiennent. Les communications sont évaluées dans l'anonymat de leurs auteurs; celles que soumettent les collègues départementaux sont référées à un comité de lecture extérieur.

Les manuscrits, en triple exemplaire, doivent être adressés à La Secrétaire à la Rédaction. Canadian Journal of Philosophy, University of Lethbridge, Lethbridge, Alberta, Canada T1K3M4. Soumettre de préférence des manuscrits (citations et notes comprises) dactylographiés à double interligne, en prenant pour guide, dans la mesure du possible, The University of Chicago Manual of Style. Les notes doivent suivre la numérotation continue et figurer sur des feuilles indépendantes en annexe au manuscrit. Les textes non insérés ne sont rendus qu'en cas de prépaiement des frais de poste par chèque, mandat, coupons-réponse, ou timbres canadiens.

Les auteurs recoivent gratuitement 25 tirés-à part de leur article. Ils sont priés, s'ils désirent en obtenir un plus grand nombre à titre onéreux, en informer l'imprimeur lors de renvoi des épreuves.

Les articles du CJP sont catalogués dans The Philosophers' Index, Bowling Green, Ohio, E-U, dans le Répertoire bibliographique de la philosophie, Louvain, Belgique, et dans l'Index de Périodiques Canadiens. 

Subscription
Information
Canadian Journal of Philosophy is published by the University of Calgary Press.

Canadian Journal of Philosophy is published quarterly, in March, June, September, and December. In addition to these regular issues, $C J P$ publishes annually a supplementary volume of original papers on a selected theme of contemporary philosophical interest. This supplementary volume is free to all subscribers to the journal in that year. Supplementary volumes may also be purchased separately from UBC Press, 6344 Memorial Road, Vancouver, BC V6T 1 Z2.

Correspondence regarding subscriptions, renewals, and single issues should be addressed to Canadian Journal of Philosophy c/o University of Calgary Press, The University of Calgary, Calgary, Alberta, Canada T2N 1N4.

A subscription for the 1997 volume of four issues plus the supplementary volume is:

$\begin{array}{lrr} & \text { Canada } & \text { Outside Canada } \\ \text { Institutions } & \mathrm{Cdn} . \$ 50.00 & \text { US } \$ 50.00 \\ \text { Individuals } & 25.00 & 25.00 \\ \text { Students } & 15.00 & 15.00 \\ \text { Single issues } & 9.00 & 9.00\end{array}$

A joint subscription to Canadian Journal of Philosophy and the Australasian Journal of Philosophy is available to individuals at $\$ 40$ and to students at $\$ 25$. Outside Canada the price is in US dollars. Canadian residents please add 7\% GST.

\section{Canadian Philosophy}

University of Calgary Press

The University of Calgary

CALGARY, Alberta, Canada

T2N $1 \mathrm{~N} 4$

\begin{tabular}{rr}
1997 Subscription $\square$ & Individual $\square$ \\
1997 Joint Subscription $\square$ & Student $\square$ \\
Back Issue $\square$ No. & \\
\hline
\end{tabular}

Please send me information on CJP Supplementary Volumes $\square$

Name

Address

City

Country Postal Code

Visa $\square \quad$ Mastercard $\square \quad$ No.

Expiry Date

Cheques should be made payable to University of Calgary Press. 
Abonnements Canadian Journal of Philosophy est publié par University of Calgary Press.

Canadian Journal of Philosophy est une publication trimestrielle paraissant en mars, juin, septembre, et décembre. Outre ses quatre fascicules réguliers, il publie, annuellement, un supplément thématique d'articles inédits consacrés à des sujets d'actualité philosophique. Le supplément est offert gratuitement à tout abonné de l'année courante. Les suppléments sont également disponibles à titre onéreux à UBC Press, 6344 Memorial Road, Vancouver, BC V6T 1 Z2.

Toute correspondance concernant l'administration (abonnements, renouvellements, commandes de numéros) doit être adressée à Canadian Journal of Philosophy, c/o University of Calgary Press, The University of Calgary, Calgary, Alberta, Canada T2N 1N4.

Tarifs d'abonnement au volume 1997 (4 fascicules et de suppléments):

$\begin{array}{lrr} & \text { Canada } & \text { Hors-Canada } \\ \text { Institutions } & \text { Cdn. 50,00\$ } & \text { US 50,00\$ } \\ \text { Individus } & 25,00 \$ & 25,00 \$ \\ \text { Etudiants } & 15,00 \$ & 15,00 \$ \\ \text { Numéro simple } & 9,00 \$ & 9,00 \$\end{array}$

Tout individu ou étudiant peut souscrire, à raison de $40 \$$ et $25 \$$ respectivement, un double abonnement au Canadian Journal of Philosophy et à l'Australasian Journal of Philosophy. Règlement en dollars US pour tous ceux qui résident en dehors du Canada. Les résidents du Canada doivent payé la TPS.

University of Calgary Press

The University of Calgary

CALGARY, Alberta, Canada

T2N 1N4
Abonnement $1997 \square$ Individu $\square$ Double Abonnement $1997 \square \quad$ Etudiant $\square$ Numéros disponsibles $\square$ No.

Veuillez me faire parvenir tous les renseignements concernant les suppléments du CJP

Nom

Adresse

Ville

Pays Code Postal

Visa $\square \quad$ Mastercard $\square \quad$ No.

Date d'expiration

Libeller tout chèque à l'ordre de University of Calgary Press. 
Other
Business
Information

Automatic

Permission

to Reproduce

\section{Back Issues}

Services

administratifs

— détails

supplémen-

taires

\section{Reproduction affranchie d'agrément préalable}

\section{Volumes antérieurs}

All business correspondence should be addressed to Canadian Journal of Philosophy, University of Calgary Press, Calgary, Alberta T2N $1 \mathrm{~N} 4$. This includes enquiries concerning advertising and promotion, exchanges, and reprinting. The copyright for all materials appearing in the regular issues and in the supplements of this journal is held by the Canadian Journal of Philosophy, and consent for any reproduction or reprinting must be obtained with the following exception.

Permission to reproduce parts of individual numbers of Canadian Journal of Philosophy by photocopy, xerox, offset, etc., for scholarly purposes (but not for republishing by printing nor for sale to the public) is automatically granted without prior permission being secured at the following rates: first 5 copies, no charge; 4 cents for each copy in excess of five of each page of CJP.

Remuneration is to be paid to the Canadian Journal of Philosophy, stating title and author of the article and number of copies. Proceeds above $\$ 10.00$ from any one article will be shared with the author. This announcement applies retroactively to volume I, number 1 .

Canadian Journal of Philosophy is indexed in Canadian Magazine Index by Micromedia Limited. Back volumes are available in microform from Micromedia Limited, 158 Pearl St., Toronto, ON M5H 1L3. 416-593-5211.

Toute correspondance administrative, à l'exception de celle qui concerne les abonnements, renouvellements et commandes de numéros et de suppléments, doit être adressée aux Canadian Journal of Philosophy, University of Calgary Press, Calgary, Alberta T2N 1N4. Ecrire à l'adresse ci-dessus pour tous renseignements relatifs à la publicité et à la promotion, ainsi qu'aux échanges et aux réimpressions. Le copyright des articles afférents aux fascicules et suppléments est propriété du Canadian Journal of Philosophy. Leur reproduction ou réimpression en tout ou partie ne peut être faite sans l'agrément préalable de le Directeur de la Publication, sauf dans le cas suivant.

Est affranchie d'agrément préalable la reproduction partielle des numéros du Canadian Journal of Philosophy par procédé technique de photocopie, xerox, offset, etc., lorsqu'elle vise exclusivement à des fins ou à des recherches académiques. Est interdite toute réimpression ayant pour objet la vente au public. Conditions tarifaires de reproduction: 1-5 copies, accordé à titre gracieux; 6 copies ou en plus, 4 cents pour chaque copie de chaque page du CIP.

Effectuer tout règlement à l'ordre du Canadian Journal of Philosophy. Avoir soin d'indiquer le nom de l'auteur et le titre de l'article à reproduire d'une part, et le nombre de copies requises, de l'autre. Les apports provenant d'un article sont partagés à égalité avec son auteur pour la part numéraire dépassant $\$ 10.00$ (règlement rétroactif au volume I, No. 1).

Canadian Journal of Philosophy est répertoirié par Micromedia ltée dans le Canadian Magazine Index et les volumes antérieurs sont disponibles en microforme chez Micromedia ltée, 158 Pearl St., Toronto, ON M5H 1L3. 416-593-5211. 


\section{CANADIAN JOURNAL OF PHILOSOPHY SUPPLEMENTARY VOLUMES}

\begin{tabular}{|c|c|c|c|c|}
\hline \multirow{3}{*}{ Vol. I } & & & $\begin{array}{l}\text { Retail } \\
\text { in } \\
\text { Canada } \\
\text { Cdn. } \$ \$\end{array}$ & $\begin{array}{l}\text { Retail } \\
\text { outside } \\
\text { Canada } \\
\text { US } \$ \$\end{array}$ \\
\hline & -1975 & $\begin{array}{l}\text { Part 1: New Essays in the } \\
\text { History of Philosophy }\end{array}$ & 10.00 & 10.00 \\
\hline & & $\begin{array}{l}\text { Part 2: New Essays in the } \\
\text { Philosophy of Mind }\end{array}$ & 10.00 & 10.00 \\
\hline Vol. III & -1977 & New Essays in Contract Theory & 13.00 & 13.00 \\
\hline Vol. IV & -1978 & $\begin{array}{l}\text { New Essays in Rationalism } \\
\text { and Empiricism }\end{array}$ & 13.00 & 13.00 \\
\hline Vol. V & -1979 & $\begin{array}{l}\text { New Essays on Mill and } \\
\text { Utilitarianism }\end{array}$ & 13.00 & 13.00 \\
\hline Vol. VI & -1980 & $\begin{array}{l}\text { New Essays in Philosophy of } \\
\text { Language }\end{array}$ & 13.00 & 13.00 \\
\hline Vol. VII & -1981 & Marx and Morality & 15.00 & 15.00 \\
\hline Vol. VIII & -1982 & $\begin{array}{l}\text { New Essays in Ethics and } \\
\text { Public Policy }\end{array}$ & 14.00 & 13.00 \\
\hline Vol. IX & -1983 & New Essays on Plato & 13.00 & 13.00 \\
\hline Vol. X & -1984 & New Essays on Aristotle & 14.00 & 14.00 \\
\hline Vol. XI & -1985 & $\begin{array}{l}\text { New Essays in the Philosophy } \\
\text { of Mind, Series II }\end{array}$ & 14.00 & 14.00 \\
\hline Vol. XII & -1986 & $\begin{array}{l}\text { Nuclear Weapons, Deterrence } \\
\text { and Disarmament }\end{array}$ & 12.00 & 10.00 \\
\hline Vol. XIII & -1987 & $\begin{array}{l}\text { Science, Morality and } \\
\text { Feminist Theory }\end{array}$ & 14.00 & 12.00 \\
\hline Vol. XIV & -1988 & Philosophy and Biology & 14.00 & 12.00 \\
\hline Vol. XV & -1989 & Analyzing Marxism & 25.00 & 21.00 \\
\hline Vol. XVI & -1990 & $\begin{array}{l}\text { Canadian Philosophers - } \\
\text { Celebrating Twenty Years of the } \\
\text { Canadian Journal of Philosophy }\end{array}$ & 24.00 & 20.00 \\
\hline Vol. XVII & -1991 & $\begin{array}{l}\text { Aristotle and his Medieval } \\
\text { Interpreters }\end{array}$ & 21.00 & 21.00 \\
\hline Vol. XVIII & {$[-1992$} & Return of the A Priori & 22.00 & 22.00 \\
\hline Vol. XIX & -1993 & Méta-Philosophie & 30.00 & 30.00 \\
\hline Vol. XX & -1994 & Biology \& Society & 30.00 & 30.00 \\
\hline
\end{tabular}

Postage and Handling (Canada/U.S.A.) is \$5.00 (1-3 books). Postage and Handling (outside Canada) is $\$ 9.00$.

Canadian orders must include 7\% GST on the total cost of the book(s) as well as the postage and handling.

Prices outside Canada are in US dollars.

Order From: University of Calgary Press

c/o UBC Press

6344 Memorial Road

Vancouver, BC V6T $1 \mathrm{Z2}$ 


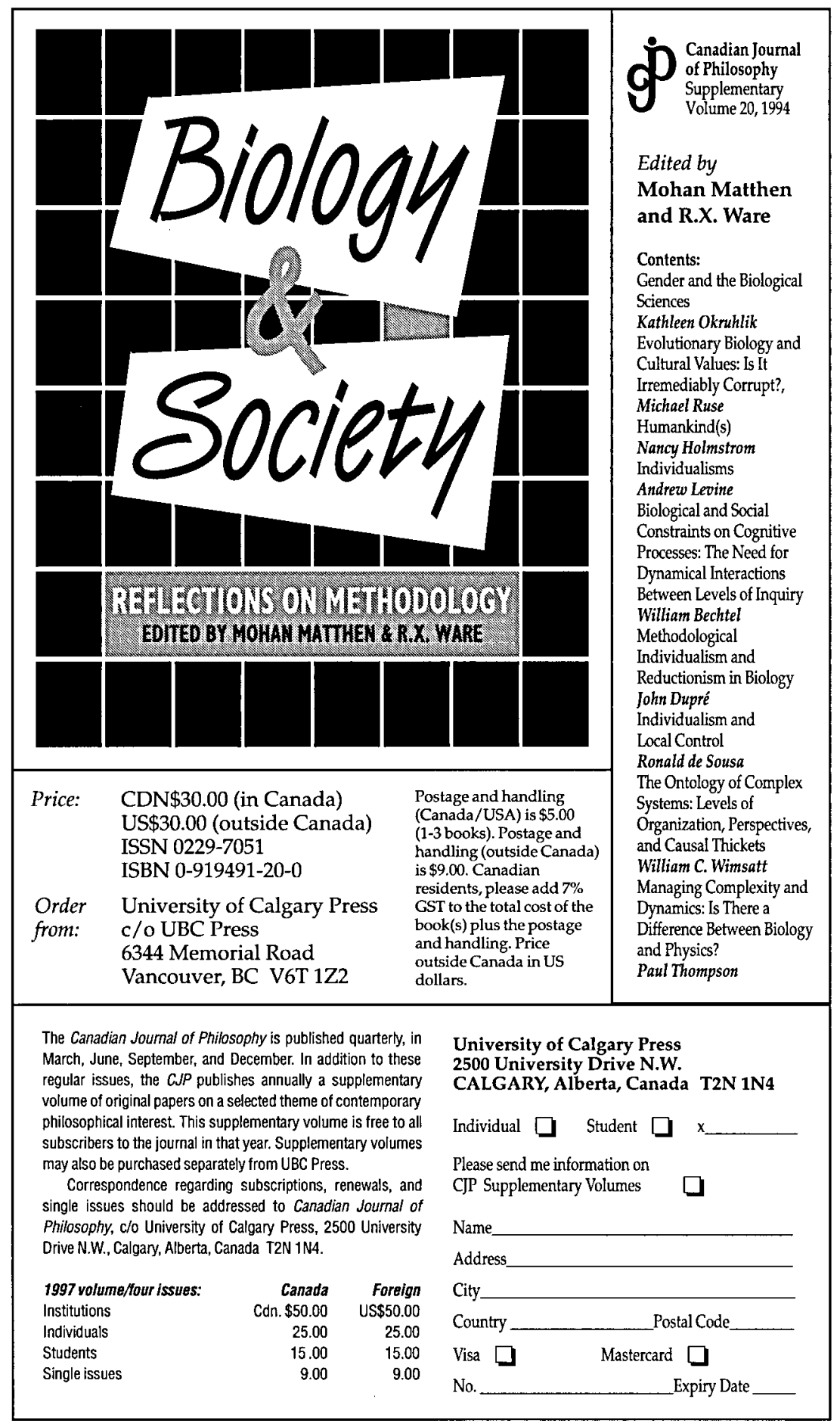




\section{The Southern Journal of Philosophy}

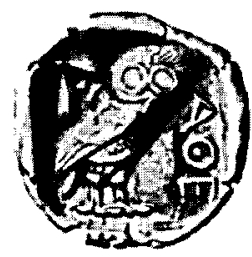

Spindel Conference proceedings only $\$ 12.00$ each

Rethinking Sex and Gender - Vol. XXXV, 1996 Explanation in the Human Sciences - Vol. XXXIV, 1995

Vagueness - Vol. XXXIII, 1994

Derrida's Interpretation of Husserl - Vol. XXXII, 1993

Ancient Minds - Vol. XXXI, 1992

Kant's Third Critique - Vol. XXX, 1991

Moral Epistemology - Vol. XXIX, 1990

Heidegger and Praxis - Vol. XXVIII, 1989

Aristotle's Ethics - Vol. XXVII, 1988

Connectionism - Vol. XXVI, 1987

B-Deduction - Vol. XXV, 1986

Moral Realism - Vol. XXIV, 1985

Recovering the Stoics - Vol. XXIII, 1984

Supervenience - Vol. XXIII, 1983

Rationalist Conception of Consciousness - Vol. XXI, 1982

Planned for 1997 is a conference on

"Kant's Metaphysics of Morals"

Proceedings published in the Spring following the conference

For more information please write or call:

THE UNIVERSITY OF MEMPHIS

SOUTHERN JOURNAL OF PHILOSOPHY

CAMPUS BOX 526104

MEMPHIS TN 38152-6104

(901) 678-2669

FAX (901) 678-4365 


\section{THE MONIST}

AN INTERNATIONAL JOURNAL OF GENERAL PHILOSOPHICAL INQUIRY

OCTOBER $1996 \quad$ VOL. 79, NO. $4 \bullet \quad$ SINGLE ISSUE, US $\$ 9$

\section{ACADEMIC ETHICS}

ADVISORY EDITOR: STEVEN M. CAHN

ARTICLES

George Sher

JOEL J. KUPPERMAN

ROBERT L. HOLMES

Nicholas Dixon

David Shatz

JOHN KEKES
My Profession and Its Duties

Autonomy and the Very Limited Role of

Advocacy in the Classroom

Sexual Harassment and the University

The Morality of Intimate Faculty-Student Relationships

Is Peer Review Overrated?

Academic Corruption

Editor: Barry Smith, State University of New York at Buffalo

Single issues, $\$ 9$ postpaid. Annual subscription: institutions, US $\$ 48$; individuals, US $\$ 25$; make checks payable to THE MONIST, Box 600 , La Salle, IL 61301 . 


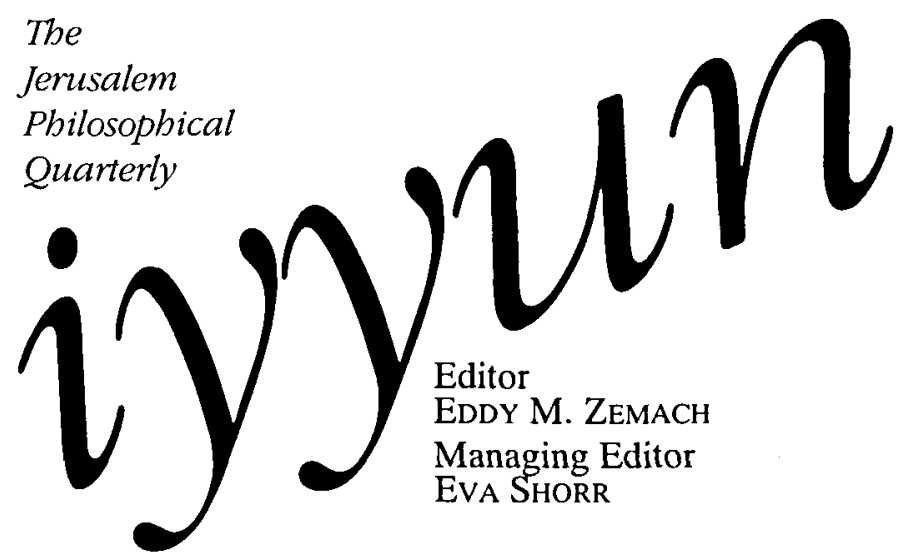

Published in Hebrew since 1945 at the Hebrew University of Jerusalem, as of vol. 39 (1990) lyyun appears four times a year: January and July in English; April and October in Hebrew. The English issues include summaries of the Hebrew articles.

Iyyun accepts long essays, articles, and critical studies irrespective of philosophical school or method of inquiry.

\section{Recent articles:}

PAUL RicoEUR: Memory, Forgetfulness, and History Mark Glouberman: Philosophy and Egypt EliJAH Millgram: Hume on Practical Reasoning KaI Nielsen: Philosophy as Wide Reflective Equilibrium JEAN-FRANÇOIS LYOTARD: Gesture and Commentary L. S. CARRIER: Skepticism about Epistemic Reasons JERrold LeVInSON: Gurney and the Appreciation of Music Richard ShUSTERman: Popular Art and Legitimation J. MARgolis: The Defeat of the Computational Model of the Mind P.M.S. HACKER: Wittgenstein on Frazer's Golden Bough JaMES HigGINBOTHAM: Truth and Understanding HARRY Frankfurt: On the Usefulness of Final Ends ChARLES PARSONS: The Uniqueness of the Natural Numbers WARREN GOLDFARB: Herbrand's Theorem and Incompleteness ANTONy Flew: Hume and Physical Necessity

Cheques should be made payable to the Jerusalem Philosophical Society and addressed to the S. H. Bergman Center for Philosophical Studies, the Hebrew University, Jerusalem 91905, Israel.

Individuals: Annual subscription: \$24; English issues only: \$15 Institutions: Annual subscription: \$27; English issues only: $\$ 18$ 


\section{Social Theory and Practice}

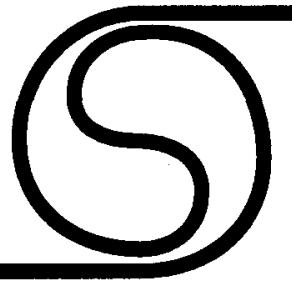

An International and Interdisciplinary Journal of Social Philosophy Volume 23, Number 1

The Moral Status of Children Samantha Brennan and Robert Noggle

Foucault and the Subject of Feminism Margaret A. McLaren

Conceptions of Persons

Fred M. Frohock

George Sher's Theory of Deserved Punishment

Stephen Kershnar

Rawls's Just Savings Principle and the Sense of Justice Roger Paden

On Disassociating Oneself from Collective Responsibility Juha Räikkä

Kantian Ethics and Global Justice

Kok-Chor Tan

Subscriptions ( 3 issues): Individuals $\$ 15$; Institutions $\$ 36$; Foreign postage $\$ 4$

Department of Philosophy, Florida State University, Tallahassee, FL 32306-1054 


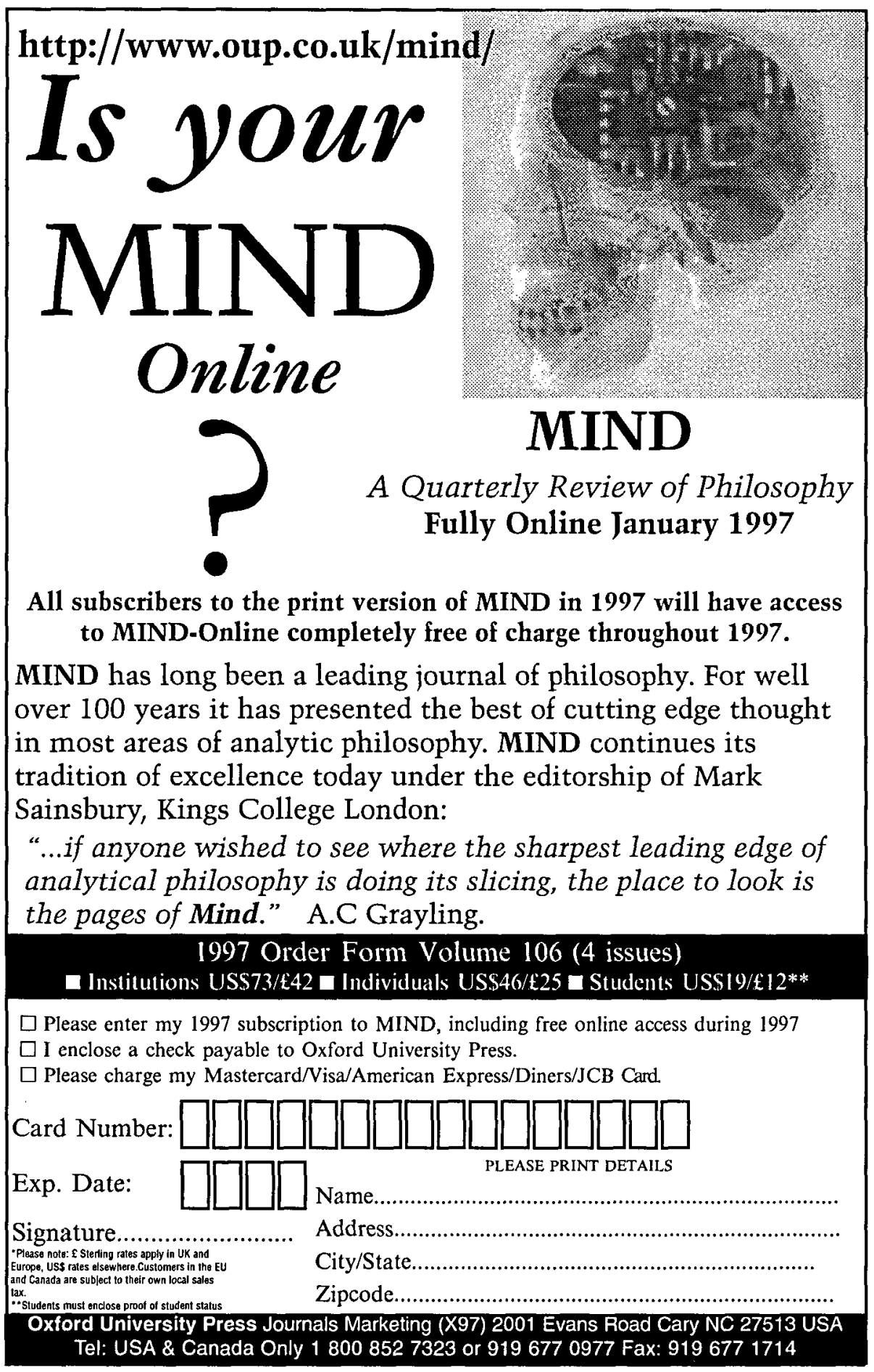


Acknowledgements/ Remerciements
Canadian Journal of Philosophy is published with the aid of a grant from the Social Sciences and Humanities Research Council of Canada.

La publication du Canadian Journal of Philosophy est rendue possible grâce à une subvention du Conseil de Recherches Humaines du Canada.

Canadian Journal of Philosophy wishes to thank the University of Lethbridge for its generous support for the editorial administration of the journal.

Canadian Journal of Philosophy tient à remercier l'Université de Lethbridge de l'aide généreuse qu'elle apporte à la gestion de sa rédaction.

Canadian Journal of Philosophy is grateful for past support from its originating sponsor, the Canadian Association for Publishing in Philosophy. The Association is a non-profit organization, incorporated under the laws of Canada, with the object of promoting and publishing learned publications in philosophy. A regular member of the Association is a member of, and appointed by, any department of philosophy in a Canadian university, upon payment of a subscription by that department. The Association is a Registered Canadian Charitable Organization within the meaning of the Income Tax Act; donations to the Association are thus tax deductible.

Canadian Journal of Philosophy désire exprimer sa gratitude à l'Association Canadienne des Publications en Philosophie qui l'a aide par le passé. L'Association est un organisme à but non lucratif, incorporé aux termes de la loi canadienne, ayant pour objet la promotion et la publication d'études savantes en philosophie. Tout membre appartenant à et désigné par, un département de philosophie d'une université canadienne est de facto, au reçu du règlement de l'abonnement départemental, membre à part entière de l'Association. L'Association est inscrite au Registre officiel des Organismes de Charité canadiens aux termes de la loi de l'impôt sur le revenu; les donations dont elle fait l'objet peuvent bénéficier ainsi du dégrèvement d'impôt. 